\title{
Review \\ The Distinctive Role of Chemical Composition in Archaeometry. The Case of Apulian Red Figure Pottery
}

\author{
Lorena Carla Giannossa $^{1,2}$ (D) , Tiziana Forleo ${ }^{1}$ (D) and Annarosa Mangone ${ }^{1,2, *}$ \\ 1 Department of Chemistry, University of Bari Aldo Moro, via E. Orabona 4, 70125 Bari, Italy; \\ lorenacarla.giannossa@uniba.it (L.C.G.); tiziana.forleo@uniba.it (T.F.) \\ 2 Centro Interdipartimentale "Laboratorio di Ricerca per la Diagnostica dei Beni Culturali (LaBC)", \\ University of Bari Aldo Moro, via E. Orabona 4, 70125 Bari, Italy \\ * Correspondence: annarosa.mangone@uniba.it
}

check for updates

Citation: Giannossa, L.C.; Forleo, T.; Mangone, A. The Distinctive Role of Chemical Composition in Archaeometry. The Case of Apulian Red Figure Pottery. Appl. Sci. 2021, 11 3073. https://doi.org/10.3390/ app11073073

Academic Editor: Giuseppe Lazzara

Received: 2 March 2021

Accepted: 25 March 2021

Published: 30 March 2021

Publisher's Note: MDPI stays neutral with regard to jurisdictional claims in published maps and institutional affiliations.

Copyright: (c) 2021 by the authors. Licensee MDPI, Basel, Switzerland. This article is an open access article distributed under the terms and conditions of the Creative Commons Attribution (CC BY) license (https:// creativecommons.org/licenses/by/ $4.0 /)$.

\begin{abstract}
Correlation of the scientific approach to the archaeological investigation and vice versa is considered, for at least the past 30 years, as the best strategy to answer questions in cultural heritage. Many archaeological queries have merged archaeological and scientific studies and have been carried out with a multidisciplinary approach that uses complementary analytical techniques. Here, we focused our efforts on outlining the strong relevance of elemental composition in chemistry and mineralogical investigations to answer important archaeological questions in the case of Apulian red figure pottery. This ceramic class is the most important quantitative handcraft production group of figured pottery in Magna Grecia and the most widespread and commercialized production from the third quarter of the fifth century to the end of the next century. The results obtained indicate that, by exploring chemical elements in the ceramic mixture, it is possible to extract information about provenance, manufacturing processes, originality and restoration techniques.
\end{abstract}

Keywords: archaeometry; chemical analyses; multivariate statistical treatments; Apulian red figure pottery

\section{Introduction}

The great contribution that scientific investigations, when applied to a well-selected and representative sample of finds and conducted according to a correct analytical method, provide to archaeological research is currently well established.

In case of ceramic finds, assessing provenance and technological features has almost always been represented as the main goal of archaeometric investigations.

Most archaeological questions can be solved using a combined mix of analytical techniques that can provide compositional and structural data about bulk and surfaces. For instance, the quantification of pottery pastes, followed by an appropriate data mining process, allows to trace the provenance [1-4] of the finds and/or of the raw materials, but also to disclose differences in the manufacturing process [5-11], to support an archeological classification [12-15], and to realize whether or not an attribution can be made [16,17].

The data mining used in the first archaeometric investigations involved scatter plots related to selected pairs of chemical elements or their combinations to extract the archeological information contained in the data set. Consequently, any type of information related to other measured variables was excluded. Over time, several multivariate statistical methods were used [18-21]. These techniques allow us to consider at the same time the contribution of a greater number of variables and possibly their synergistic effect, removing the spurious information and highlighting useful information. Among these, linear principal component analysis (PCA) and clustering analysis (CA and HCA) continue to be the widely used.

The actual origin of objects can be assessed comparing their chemical compositional data with reliable indicators of production (kiln dumps, wasters, etc.). However, if objects of a known provenance are not available, it is possible to hypothesize the origin of the finds 
through the compositional similarity of a statistically representative set of items, while directly correlating the provenance of the finds to the provenance of the clay alone is not immediate because the complexity of the manufacturing process used (possible mixing of clays with different mineralogical and chemical characteristics, intentional addition of tempers of various types and origins (grog, sand, etc.), firing, painting, glazing). It should also be considered the question of accessory minerals, often indicators of different clayey sedimentary basins, but those presence, because of the limited amount, does not influence the major elements chemical composition. However, their identification and the identification of their accurate composition allow us to recognize or to exclude the use of a given sedimentary deposit.

The chemical compositional analysis is not sufficient to fully clarify the manufacturing processes employed, which should always be supported by the identification of the mineralogical composition of pastes. In this respect, the determination of the maximum firing temperature, the duration of firing and the kiln atmosphere can be reconstructed through the identification of some newly formed phases related to firing [22-26]. Chemical and mineralogical data on ceramic pastes and coatings are also essential in restoration and forensic fields to recognize not recorded restoration action or forged vases (or part of them).

In this paper, the focus is on the Apulian (Southern Italy) red figure pottery (Figure 1) with the aim to integrate the data we obtained on finds from specific sites [8,11,27-32] into a more cohesive picture. Sections are assembled according to the type of information provided.

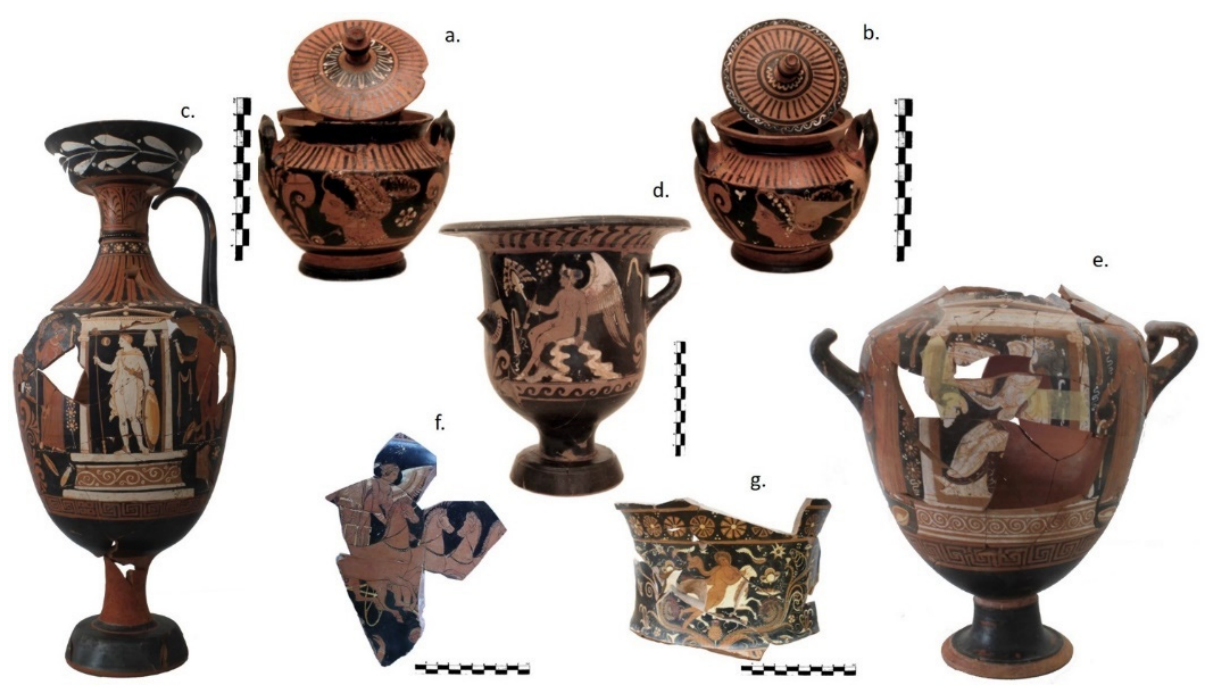

Figure 1. Apulian red figure samples analyzed coming from Arpi (a-e) and Taranto (f,g).

\subsection{Archaeological Background}

Apulian red figure pottery is the southern Italy variant of the renowned Attic production. In both cases, figures on the vase were obtained saving the ceramic body from the black glossy background, occasionally some accessory colors (white, yellow, brow, etc.) were present.

The production of Apulian red figure pottery took place in Apulia from the third quarter of the fifth century BCE to the end of the next century (three periods are formally recognized: Early (440-370 BCE), Middle (from 370 to 340-330 BCE) and Late Apulian (340-300 BCE)) [33-35]. As far as concerns red figure pottery produced in Magna Graecia, Apulian red figure pottery is the most numerically significant group, which was most widespread and available on the market. Its production also required great production skills and is of great quality.

The traditionally accepted date for the beginning of this type of manufacture is 440 BCE. Between 450 and 300 BCE a transitory transfer of skilled craftsmen and artists occurred from Taras (Taranto) to the wealthiest Apulian villages, so that these centres became branches of production outside the main polis (city). 
The organization of production in workshops was complex and well planned. Production increased throughout the fourth century BCE, but mainly in the Late period, when iconographically and formally excellent handcraft pieces coexisted with low quality, mass production pieces. The Middle and Late periods are the most fascinating to be studied because a greater number of unsolved questions can be found [36].

Apulian red figure pottery has been extensively investigated by archaeologists and numerous studies are available in the literature (please refer to them for more detailed stylistic-typological information). Scientific papers are few, mainly dealing with Attic production and aimed at understanding the specific characteristics of each individual step in the overall production cycle, with particular attention being paid to the technique utilized to make black gloss, and they are fragmented into different investigation sectors [37-70]. A more limited number of papers have focused on Attic overpainting colors $[47,58-62,67,71,72]$, especially white, yellow and red.

Fewer studies are available on pottery production in Magna Graecia and in Puglia particularly. Most part of them are devoted to assessing the provenance of finds $[14,64,73-79]$ and fewer to identify technological features $[8,11,28-32,36,56,78,80-84]$. Often the items investigated were museum objects or seized material examined to verify their authenticity $[27,85,86]$.

Although the Apulian red figure class has not been studied as thoroughly as Attic pottery, the picture emerging from archaeometric investigations is of great interest.

\subsection{Analytical Methods and Multivariate Statistical Treatments}

Archaeological sampling surely represents a compromise between the safeguard of the priceless artworks under investigation and the requirement to obtain a representative sample for chemical and mineralogical analyses. In case of bulk analysis, we scrape off bulk ceramic powders from objects already fragmented or from hidden areas from inside or under the base of the vases, after eliminating the outermost external contaminated layer and without damaging the aesthetic of the object. Aliquots of about $60 \mathrm{mg}$ of bulk ceramics [87] are then weighted and dissolved by acid digestion. The chemical dissolution of the ceramic bodies is carried out according to the procedure described in references [8,9]. Fragments, on the other hand, were sampled by collecting a few square millimeters wide shards from their edges. In addition to chemical investigations, we also perform minero-petrographic analyses to acquire info about technological production, possible integrations, etc.

Typically, bulk analyses to define the elemental chemical composition of ceramic bodies of this ceramic class are performed by atomic spectroscopies (AAS, ICP-OES, ICPMS), X-ray fluorescence spectroscopy (XRF), laser ablation Inductively Coupled Plasma Mass Spectrometry (LA-ICPMS). Compositional data (major, minor and traces elements) are generally treated by multivariate statistical treatments to find clusters distinguishable for provenance, manufacturing process and archaeological class.

Optical microscopy (OM), scanning electron microscopy with Energy Dispersive Xray Spectroscopy (SEM-EDS) or Wavelength Dispersive X-ray Spectroscopy (SEM-WDS) and X-ray diffraction (XRD) are usually utilized to define the ceramic bodies mineralogical composition.

The multivariate statistical treatments proposed in this paper are NLPCA (nonlinear principal component analysis) and DA (discriminant analysis). NLPCA and DA are techniques based on the transformation of the original data $[75,88]$. NLPCA ignores class labels and finds directions of maximal variance and is used as an exploratory approach. DA gives a classification model, knowing a priori the classes in which the data set is divided, and attempts to find a feature subspace that maximizes class separability.

PCA graphic takes place plotting the score and loading vectors of the different parameters in the subplane of the first two or three principal components. However, the application of PCA to characterize data showed severe limitations because of its linear feature [75]. In this case, a nonlinear generalization of standard PCA by replacing linear surfaces with curved ones can be the right answer. 
In this work, we consider hierarchical NLPCA based on Auto-Associative Neural network models. This method was already successfully tested on some Apulian red figure pottery [75]. To evaluate how good the model fits the data, two fitting parameters are considered: $R^{2}$ and the Lack of Fit (Lof). The Lof is the square root of the ratio between the sum of square of residuals and the total variance of the original dataset. The $R^{2}$ is the complement to 1 of the Lof square. The statistic $R^{2}$ is the fraction of variance explained by the analysis. The best model fitting of the experimental data is achieved when $R^{2}$ is closer to 1 and/or Lof to zero. When the noise is low, Lof provides more discrimination between models, otherwise when there is a larger noise contribution $R^{2}$ is preferred.

DA is a classification approach taking part of supervised techniques [88], less used in the archaeometric field, to discriminate samples based on different provenances $[89,90]$ and styles [91]. It finds those directions that maximize the ratio between the between-class variance and the within-class. If the classes are separated by hyper-planes, the DA is linear (LDA), otherwise if the boundaries of the class are quadratic the method is named quadratic discriminant analysis (QDA). The validation of the model is carried out by cross validation $(\mathrm{CV})$. All quality parameters, that describe the goodness of a model, are obtained from the confusion matrix $(\mathrm{CF})$-a square matrix of $\mathrm{GxG}$ dimension, where $\mathrm{G}$ is the number of classes-. The diagonal elements are the objects correctly classified; the off-diagonals are the wrongly classified ones. The non-error rate (NER) represents the percentage of elements correctly classified and it is the ratio between the diagonal element and the total number of objects. Data processing was performing by the R V3.3.3 software (R Core Team, Vienna, Austria) with the packages "MASS" [92] and "pcaMethods" [93].

\section{Archaeological Questions/Archaeometric Answers}

\subsection{Authenticity: Original Versus Fake}

Research objectives can be addressed to:

(a) checking the nonauthenticity of a find or some parts of it, that could have been integrated during restoration (eventually, understanding where and when the integration was added); establishing the belonging of sporadic fragments to a single vase, when it is not possible based on well-known restoration procedures;

(b) identify undocumented repainting on the surface of the vases. As a matter of fact, understanding if the surface of the vase is original is essential if you want to use nondestructive techniques, that inevitably analyze the more superficial layers.

The above-mentioned aims are particularly important for this ceramic class, especially considering the high attention, since the end of the nineteenth century, museums and collectors have paid to it. This interest has led to an increase in excavations and sales of vases, making tomb robbing a business of colossal dimensions. Many objects have been sold on the domestic and international black markets, an illegal trade which is today worth over four billion dollars a year $[94,95]$. To put this into perspective, only the black-market trade in arms and drugs involve a higher turnover. Vases were often broken into small pieces to transport them more conveniently and then put back together without any kind of care for ancient and technological process. Sometimes, fragments were assembled from different vases or integrating the missing parts with parts specifically produced to increase the commercial value of the object. In this way, particularly in the case of artifacts excavated in more ancient times, important information such as the origin of the object and the context of excavation have been lost. Some vases acquired in the past, even by famous museums, have sometimes been assembled with original and nonoriginal pieces [96].

Some examples of information that can be obtained by archaeometric investigations to achieve the abovementioned objectives are reported below.

(a) Case study. Fragments: nonauthenticity or common origin.

Two important Apulian red figure vases (a krater and a loutrophoros) stored in the National Archaeological Museum of Naples (MANN) were investigated [27]. Both items were acquired from private collectors of Ruvo di Puglia in the nineteenth century and were 
subjected, through the ages, to several unrecorded restorations (the first ones probably carried out before the vases arrived at the MANN). The krater called dell'Amazzonomachia was attributed to Dario Painter (about 330 BCE) and the loutrophoros with the myth of Niobe to Varrese Painter (about 350-340 BCE). Doubts before archaeometric analyzes were focused exclusively on authenticity of a handle of the krater and both handles of the loutrophoros.

The archaeometric results have allowed to assess the nonauthenticity of the krater handle and the whole upper part of the loutrophoros (in addition to the handles).

Experimental results have supported the use of different raw materials for the body and the handle of the krater and body and the whole superior part of the loutrophoroshandles included. These hypotheses were based on differences in chemical (Table 1) and mineralogical composition of the pastes (silty-grain size and sintering degrees) and crystals shapes-especially quartz (Figure 2).

Table 1. Composition by ICP-MS of the ceramic bodies collected from the krater, the cercine and the loutrophoros.

\begin{tabular}{|c|c|c|c|c|c|c|c|c|c|c|c|c|c|c|}
\hline Sample & $\mathbf{F e}$ & Al & $\mathrm{Mg}$ & $\mathbf{K}$ & $\mathbf{T i}$ & $\mathrm{Na}$ & $\mathrm{Ca}$ & Mn & $\mathbf{P b}$ & $\mathbf{N i}$ & Sr & $\mathrm{Cr}$ & Ba & Zn \\
\hline & \multicolumn{7}{|c|}{$(\% w / w)$} & \multicolumn{7}{|c|}{ (ppm) } \\
\hline Krater basin & 5.17 & 9.96 & 1.48 & 2.38 & 0.55 & 0.72 & 6.70 & 959 & 192 & 78 & 316 & 131 & 407 & 131 \\
\hline Krater handle & 2.96 & 9.24 & 0.55 & 2.56 & 0.32 & 0.62 & 7.55 & 865 & 1256 & 28 & 123 & 51 & 364 & 43 \\
\hline Cercine & 4.20 & 10.89 & 1.93 & 2.57 & 0.43 & 0.74 & 7.89 & 740 & 811 & 63 & 386 & 141 & 295 & 99 \\
\hline Loutrophoros foot & 5.01 & 8.99 & 1.37 & 2.26 & 0.51 & 0.54 & 6.99 & 1267 & 57 & 68 & 280 & 102 & 350 & 119 \\
\hline Loutrophoros basin & 5.04 & 8.89 & 1.39 & 2.26 & 0.51 & 0.51 & 6.54 & 1126 & 34 & 88 & 310 & 133 & 388 & 117 \\
\hline Loutrophoros neck & 3.91 & 5.70 & 1.66 & 1.87 & 0.33 & 1.91 & 11.41 & 658 & 183 & 142 & 745 & 343 & 328 & 137 \\
\hline Loutrophoros neck edge & 3.90 & 7.09 & 1.85 & 2.15 & 0.38 & 0.60 & 8.92 & 956 & 10,869 & 70 & 456 & 103 & 422 & 164 \\
\hline
\end{tabular}
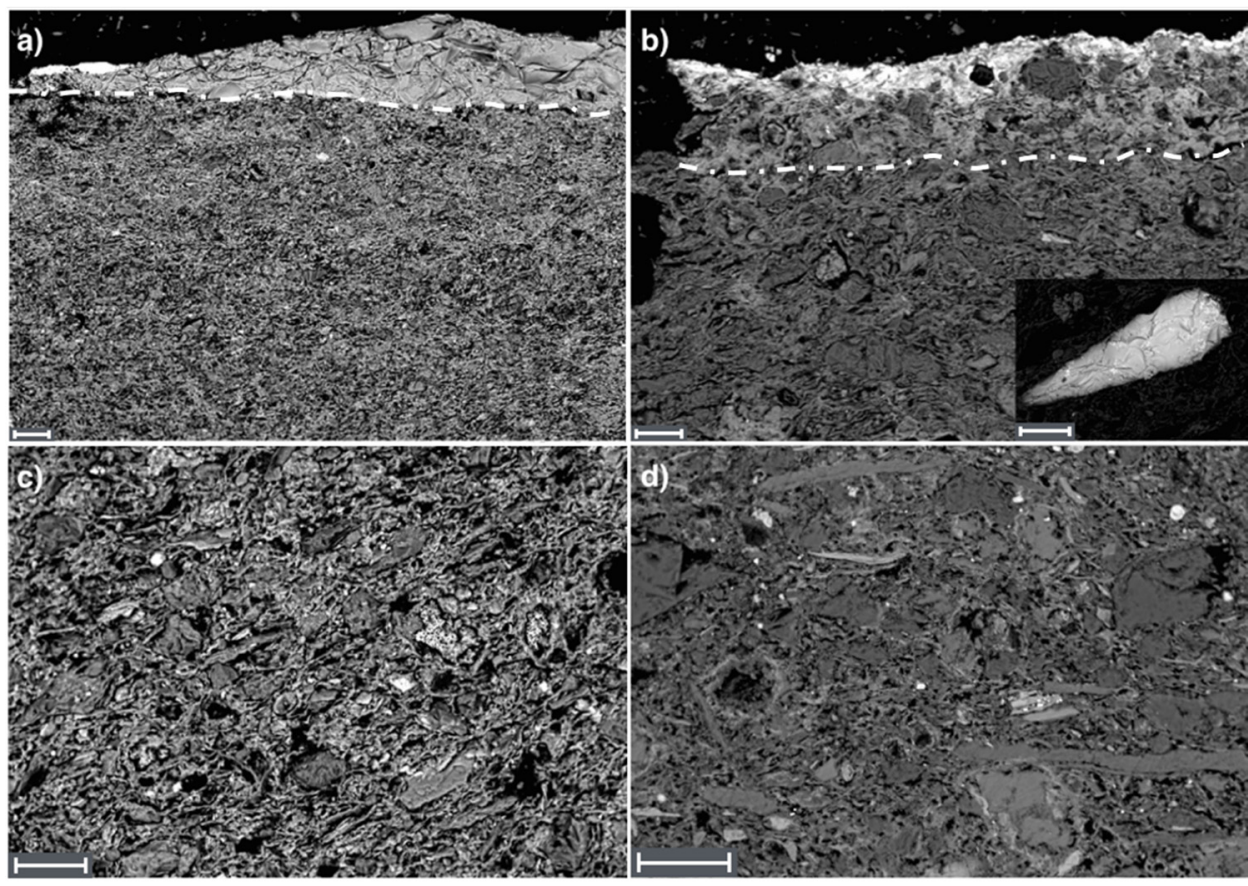

Figure 2. SEM-BSE photomicrographs of thin sections of the ceramic body of the krater dell'Amazzonomachia: basin (a), handle (b) (Inset: crystal of lead silicate inside the paste.), the cercine (c) and the neck of Loutrophoros (d). Scale 30 micron. Dashed lines separate the ceramic body and the surface decoration: the traditional black gloss and the repaintings on it (brighter) (a), the layer based on Pb newly formed silicates, Mn and Sn simulating the traditional black gloss (upper) (b).

In the mixture of the handle of the krater, numerous crystals of lead silicatesinevitably linked to the raw material used to create the surfaces of the nonauthentic pieces-have been observed (Figure 2). Moreover, the similarity of the material used (Figure 2c) for the cercine (the ceramic support used to transport the vase and therefore 
reasonably made in the same place where the object was found) and for the handle of the krater support the hypothesis regarding the addition of the krater handle after its recovery and suggests that this restyling was carried out in Ruvo (where the krater came from) and not, after the purchase, in Naples.

Although the nonauthenticity of the neck of the loutrophoros had not been highlighted by autoptic examinations, it was suggested by restorers during the dismantle phase of parts [97], which observed the lack of congruence in shape between the neck and the body. It must, therefore, be assumed that this part has been made in modern times (nineteenth century BCE) and added during restoration. As a matter of fact, a joint band between the neck and body was added to fix the shape inconsistence. The camouflage was completed thanks to a decoration seamless between the figurative scenes, observable in the first photographs, and later succeed by an achromatic integration, as shown in the more recent images. Both handles of the loutrophoros, as it had already been assumed during the first restorations, were not authentic and were made with a paste based on glue and plaster. Although the black surfaces of the nonauthentic parts, for both vases, are lead-based, the diversity in the materials mixed to lead in the two cases could indicate a manufacturing in different workshops.

An example of determining the common origin of sporadic fragments to a single find is hereafter illustrated.

The fragments analyzed come from the residual edges of a tomb filling, which underwent a clandestine excavation in the past and recently it was excavated by the Commission for the Architectural and Landscape Heritage for the Provinces of Barletta-Andria-Trani and Foggia (Puglia, Southern Italy). Independent investigative activities related to criminal affairs had led to the seizure by the Guardia di Finanza of Foggia of a group of highly artistic and manufactured Apulian red figure vases, dating back to the fourth to third century $\mathrm{BCE}$, in excellent state of conservation. Since during the excavation, ceramic fragments similar based on archaeological studies with the seized finds were found, archaeometric analyzes were carried out to verify their relevance to the same context. Results pointed out strong chemical, shown in Figure 3, and mineral-petrographic similarities among seized vases and fragments recovered from the tomb, made it possible to verify the relevance of a large part of seized vases to the tomb complex under investigation.

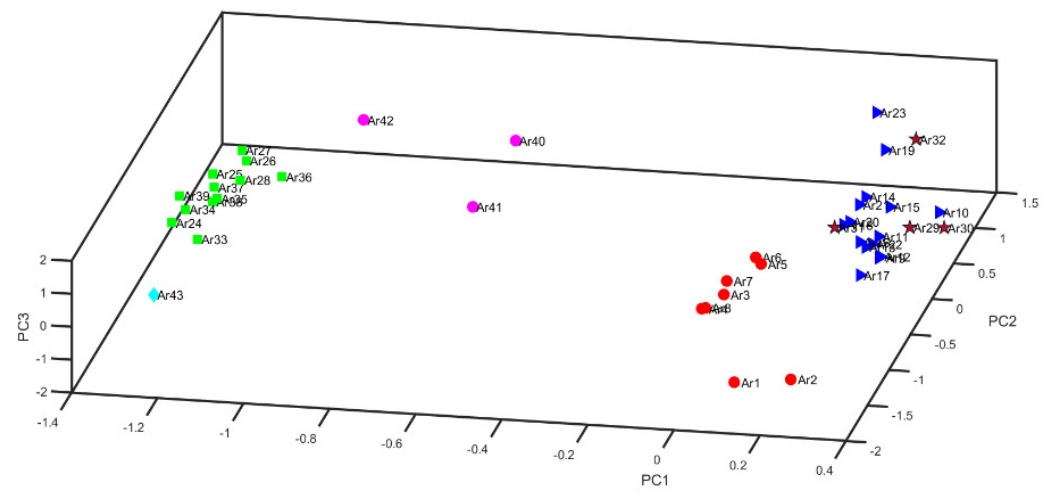

Figure 3. Scores plot (PC1, PC2, and PC3) of the NLPCA model for samples from Arpi (blue triangles and magenta circles: vases seized by the Guardia di Finanza of Foggia, red stars edged in black: sporadic fragments from ONC28 tomb of Arpi, green squares: vases from tomb of Niobids, red circles: vases from Tomba 5/2005, cyan diamond: vase from Tomba 4/2005). The fitting values obtained are 0.84 and 0.40 for $R^{2}$ and Lof, respectively. The parameter $R^{2}$ is closer to 1 than Lof to zero, confirming a high noise contribution.

(b) Case study. Surfaces: undocumented repainting.

Reintegration examples involving Apulian red-figure vases are numerous and almost never documented. 
Most common materials used in most ancient restorations are based on $\mathrm{Pb}$, added with $\mathrm{Ba}$, sometimes Sb, Sn and C (Figure 4a,b) [27,28] to obtain the black coloring of the surfaces and with $\mathrm{Hg}$ sometimes added with $\mathrm{Sn}$ to paint the red ones [98].
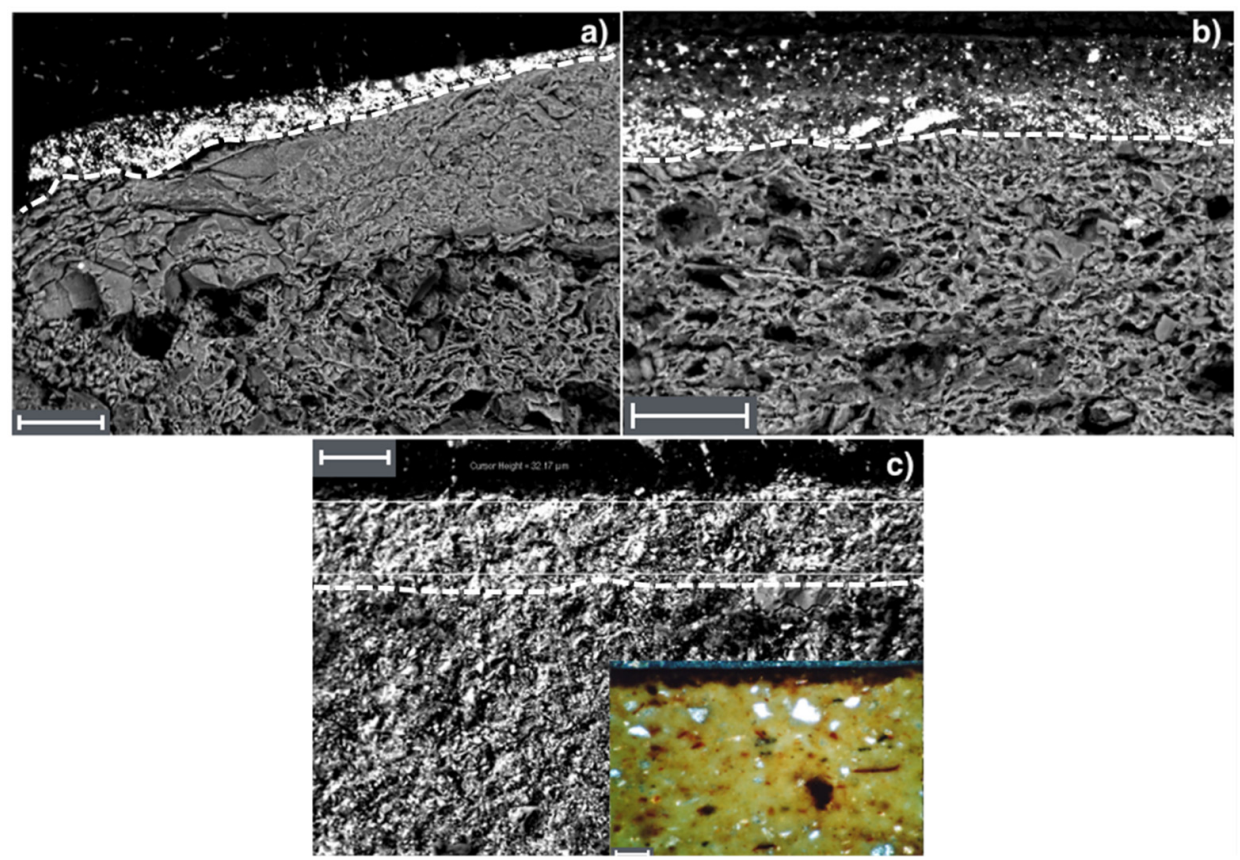

Figure 4. SEM-BSE photomicrograph of thin sections of samples of Caputi-Intesa Sanpaolo Collection [28] $(\mathbf{a}, \mathbf{b})$ and tomb of Niobids (c, inset: OM image of the same area.). Dashed lines highlight the repaintings on the black gloss (a), on the ceramic body (b) and a layer applied instead of the traditional black (c). Layers are based on: (a) $\mathrm{Pb}$ (small grains) and $\mathrm{Sr}+\mathrm{Ba}$ (large grains) in organic matrix, (b) upper layer: $\mathrm{Pb}$ (large grains) and $\mathrm{Ba}$ (small grains) in organic matrix and lower layer: $\mathrm{Pb}$ (large grains) and $\mathrm{Pb}+\mathrm{Sb}$ (small grains) in organic matrix; (c) Mn and Fe. Scale 30 micron. Inset scale 85 micron.

Repainting based on Mn and Fe was highlighted on the black surface of vases of the tomb of the Niobids (Arpi, Foggia) (Figure 4c) [98] and are attributable to a more recent restoration (around 1960).

It is noteworthy to mention that any restoration action, even if merely performed on the surface of the find, can lead to the contamination of the original material of the underlying ceramic body, characterized by a non-negligible porosity, even in its innermost part. This could make chemical analyses to assess the provenance of finds/raw materials worthless. The gluing operations of fragments should be adequately documented because they can lead to a contamination of the ceramic body too. For instance, Figure 5 shows $\mathrm{NaCl}$ contamination highlighted in depth in the ceramic body. This is the result of a treatment performed on the surface of a vase from the tomb of the Niobids in Arpi during the restoration.

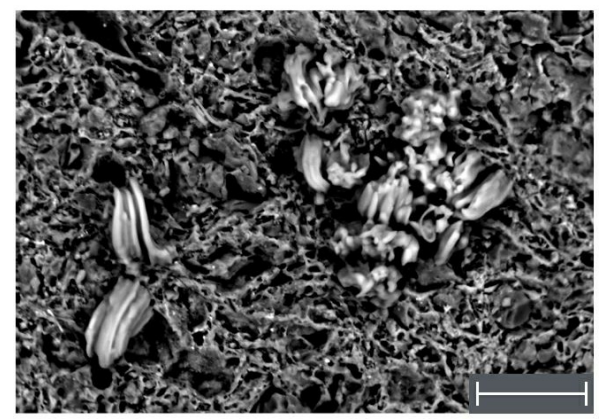

Figure 5. SEM-BSE photomicrograph of thin sections of a sample of tomb of Niobids (Arpi) highlighting the contamination of the ceramic body by $\mathrm{NaCl}$. Scale 20 micron. 


\subsection{Provenance: Importation Versus Local Production}

As previously said, the aim of this paper is to integrate the data on the Apulian red figure pottery obtained on finds from specific sites into a more cohesive picture.

The chemical data obtained for each archaeological site have been then assembled into a single matrix and analyzed using traditionally (DA) and innovative (NLPCA) multivariate statistical analysis techniques. Preliminary investigations were conducted on the original matrix of 30 chemical elements ( $\mathrm{Fe}, \mathrm{Al}, \mathrm{Mg}, \mathrm{K}, \mathrm{Ti}, \mathrm{Na}, \mathrm{Ca}, \mathrm{Mn}, \mathrm{Co}, \mathrm{Cu}, \mathrm{Pb}, \mathrm{Ni}, \mathrm{Sr}, \mathrm{Cr}, \mathrm{Ba}$, $\mathrm{Sn}, \mathrm{Zn}, \mathrm{Li}, \mathrm{V}, \mathrm{Zr}, \mathrm{Cs}, \mathrm{La}, \mathrm{Ce}, \mathrm{Sn}, \mathrm{Tb}, \mathrm{Yb}, \mathrm{Lu}, \mathrm{Eu}, \mathrm{Nd}, \mathrm{Dy})$. Statistical technique, based on comparing the means and the variances of the different variables, was applied as a criterion to reject those chemical elements that introduce noise and make more difficult the exploratory analysis and the subsequent classification. Therefore, statistical treatment was performed on a concentration matrix of 11 chemical parameters $(\mathrm{Fe}, \mathrm{Al}, \mathrm{Mg}, \mathrm{K}, \mathrm{Ti}, \mathrm{Na}, \mathrm{Ca}$, $\mathrm{Mn}, \mathrm{Ni}, \mathrm{Sr}, \mathrm{Cr})$.

To clarify if Apulian items were locally produced or imported, a bibliographic research on compositional data of Attic red figure finds has been carried. The statistical treatment comparison to detect similarities and/or differences has been performed regards Attic samples coming from different Greek sites -Atene, Perati, Rafti, Thorikos, Aigina, Megara- [51], whose chemical bulk data have been obtained by applying Atomic Spectroscopy techniques and are thus immediately comparable to our Apulian ones. Common parameters are $\mathrm{Fe}, \mathrm{Al}$, $\mathrm{Mg}, \mathrm{Ti}, \mathrm{Na}, \mathrm{Ca}, \mathrm{Ni}, \mathrm{Cr}$, which unfortunately implies that useful information obtainable by other minor and trace elements contents are missing. Results (Figure 6a) highlight a strong compositional diversity of ceramic bodies of finds from Apulian sites and Greek ones, so making it possible to discriminate between Apulian and Attic production, allowing to identify imported and locally produced objects. For example, it was possible to confirm the importation of a sample (code T38, inventory number 227208), excavated in Taranto which, based on archaeological investigations, was believed to be made in Greece. Its score position, in fact, inside the Attic cluster and far from the Apulian one, shows a greater compositional similarity to the Attic samples than to the Apulian ones.

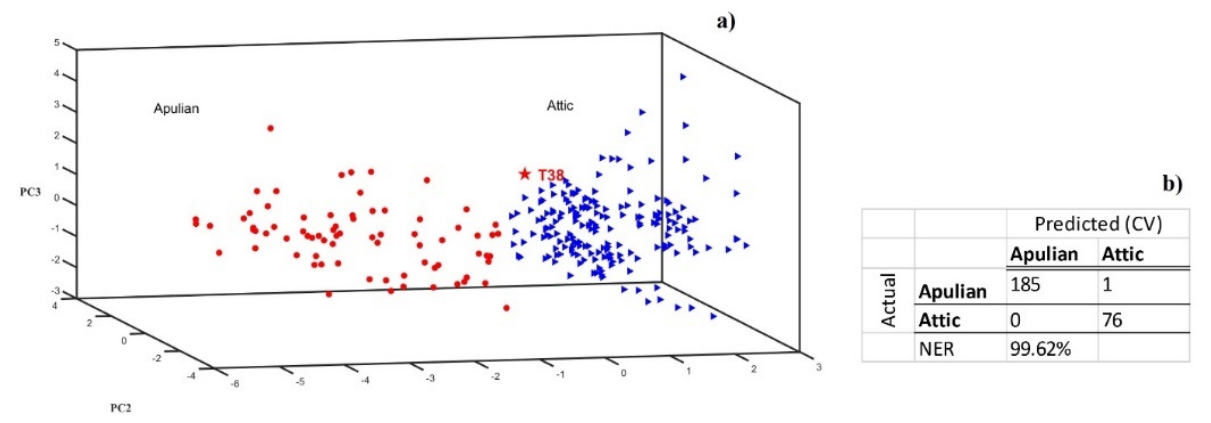

Figure 6. (a) Scores plot of the NLPCA model related to finds from Apulia (red) and Greece (blue), $\left(R^{2} 0.89\right.$ and Lof 0.34$)$. Sample T38 is marked with a star. (b) Confusion matrix and NER value obtained with the application of QDA on data.

The same conclusion can be deduced using a QDA model computed by considering the Attic and Apulian classes a priori. In the table (Figure 6b), the parameters evaluating the quality of the model are summarized. The NER shows that the $99.62 \%$ of the total samples are correctly classified. Output analysis highlights that only the sample T38 is classified in another class.

The mineral-petrographic investigations [29], highlighting for T38 a mineralogical composition dissimilar to Apulian samples, strengths the hypothesis of a sample importation.

Excluding samples of suspected imports, all the analyzed Apulian samples have been treated by NLPCA. The results highlight three different clusters that follow the ancient division of Apulia (Peucetia, Messapia and Daunia) (Figure 7a), proving the existence of a polycentric production [99]. The fitting values in the terms of $R^{2}$ and Lof, 0.96 and 0.19 , respectively, indicate that the better model fitting is achieved when at least the first 
3 principal components are considered. Compositional data matrix included data relating to finds which historical sources indicate to come from Ruvo di Puglia: the samples of the Caputi-Intesa Sanpaolo collection, kept at Gallerie d'Italia Leoni Montanari [28] in Vicenza (Italy) and the two vases kept at MANN [27]. LDA application shows that the $98.62 \%$ of the samples are correctly classified. All 52 Daunian and 38 Messapian samples are recognized to be belonged to the a priori classes. Only 2 of 55 Peucetian samples are classified as Daunian and Messapian ones (Figure $7 \mathrm{~b}$ ). The same dataset was already analyzed by applying the linear PCA. Unsatisfactory values of Lof and $R^{2}(0.54 ; 0.70)$ are achieved when the first three PCs are considered. This condition can arise when the nonlinear effects and the contribution of the noise are relevant. The score plot is shown in Figure 7c.

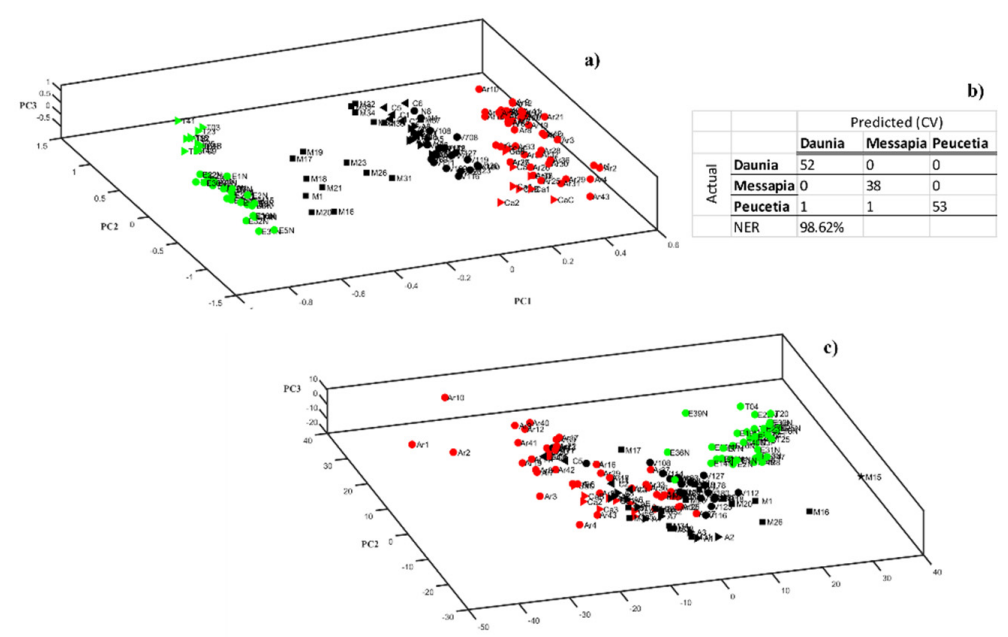

Figure 7. (a) Scores plot (PC1, PC2, and PC3) of the NLPCA model for samples belonging to three different areas of Apulia (Peucetia (black: triangles Conversano, squares Monte Sannace, circles Ruvo di Puglia, diamonds Altamura), Messapia (green: triangles Taranto, circles Egnazia) and Daunia (red: circles Arpi, triangles Canosa). (b) Confusion matrix and NER value for the LDA model built considering as priori classes Daunia, Messapia, and Peucetia. (c) Scores plot (PC1, PC2, and PC3) of the PCA model. Samples labelled as NLPCA model (a).

As concern Taranto finds, the availability of some indicators of production -a probable firing tester [100] and two stick of clayey raw material- coming from a coeval pottery workshop located in Taranto, producing black gloss and plain ware [101] made it possible to confirm the Tarentine manufacture of a group of finds excavated in the town, which on a stylistic basis were attributed to painters considered to be among the major exponents of the local school -Tarporley, Truro, and Hoppin- (Figure 8) [29].

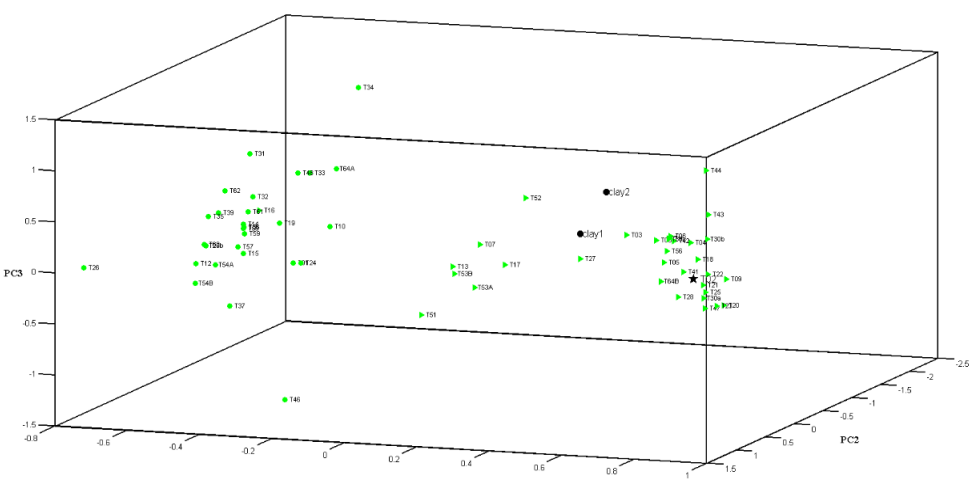

Figure 8. NLPCA scores plot related to finds from Taranto. The fitting parameters with 3 PCs are $R^{2}=0.81$ and Lof $=0.43$. Taranto finds: green triangles Apulian manufacture, green circles traditional manufactures. Black star: a probable firing tester. Black circles: clayey raw materials from a coeval pottery workshop located in Taranto [100,101]. 


\subsection{Workshops Location: Painters Transfer Versus Vases Transfer}

The workshop locations of different painters and the question of whether it was objects or the painters themselves who moved among Apulian sites represent an aspect of considerable relevance in the study of Apulian red figure productions.

A first attempt to answer this question was made by analyzing nine vases stylistically attributed to Dario Painter, excavated in various sites (tomb of Niobids in Arpi [102], hypogeum of Varrese in Canosa [103], military arsenal area at Taranto). The analysis included the krater of the Amazzonomachia supposed coming from Ruvo di Puglia [104], Table 2.

Table 2. Apulian red figure vases stylistically attributed to Dario Painter analyzed.

\begin{tabular}{cccc}
\hline Code & Inv. $\mathbf{n}^{\circ}$ & Description & Site \\
\hline Ar2 & 132734 & Oinochoe, Tomb of Niobids & Arpi \\
Ca2 & 8925 & Deinos, Hypogeum of Varrese & Canosa \\
T1 & 51381 & Volute krater with Frisso on the ram & Taranto \\
T19 & 227162 & Pelike with quadriga & Taranto \\
T26 & 227196 & Krater with Athena's head & Taranto \\
T29 & 227199 & Krater with quadriga driven by a Nike with standing & Taranto \\
T35 & 227205 & Fragment with seated Athena leaning on her shield & Taranto \\
T36 & 227206 & Fragment with body of a paniskos holding & Taranto \\
N4 & 81667 & a flute in his right hand & Ruvo di Puglia \\
\hline
\end{tabular}

The NLPCA model was built with 5 PCs with a $R^{2}$ of 0.92 and a Lof of 0.29 . A good fitting is graphically seen with $3 \mathrm{PCs}\left(R^{2}\right.$ of 0.83$)$. The results of the treatment of data by NLPCA are shown in Figure 9, illustrating the scores plotted on to the first three principal components subspace. Markedly distinct groups can be identified. The classification model created with a LDA shows a NER of $96.84 \%$. Almost all samples are assigned to the a priori classes. It was not possible to build a QDA model due to the low number of the Canosa samples in the dataset.

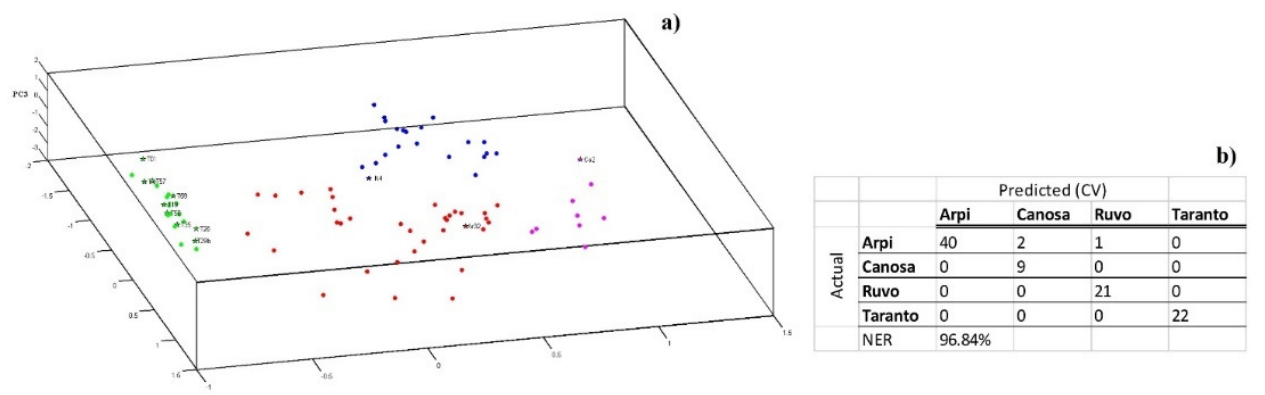

Figure 9. (a) NLPCA scores plot for the first three PCs related to the finds from Arpi (red), Canosa (magenta), Taranto (green), and Ruvo (blue). The $R^{2}$ and Lof of the model with 3 PCs were 0.83 and 0.41 , respectively. The samples attributed to Dario' painter, found in the same sites, are labelled by stars. (b) Confusion Matrix and NER value for the classification model built with LDA considering as a priori classes Arpi, Canosa, Taranto, and Ruvo.

It can be observed in Figure 9 that the scores of the samples relating to vases attributed to the same painter but coming from different sites are not in the same cluster, but in the cluster containing red figure vases coming from the same site.

Although the number of items analyzed have to be enlarged to increase the significance of the statistical processing, it would seem reasonable to assume that the distinction among finds is mainly derived from the geographical origin of the vessels, so making more reasonable to hypothesize the transfer of painters rather than of artifacts between the main Apulian sites, by reason of demand from local customers, in a context of fragmented local production. 


\subsection{Manufacture: Tradition Versus Innovation}

As concerns production technology, scientific studies, as mentioned above, have highlighted that two different manufacturing procedures were used in Apulia during the fourth century BCE. Some vases were produced using classic Attic technology, others with a previously unknown and different process that involved the application of a red engobe layer on the ceramic body before the application of black gloss (Figure 10) [8].
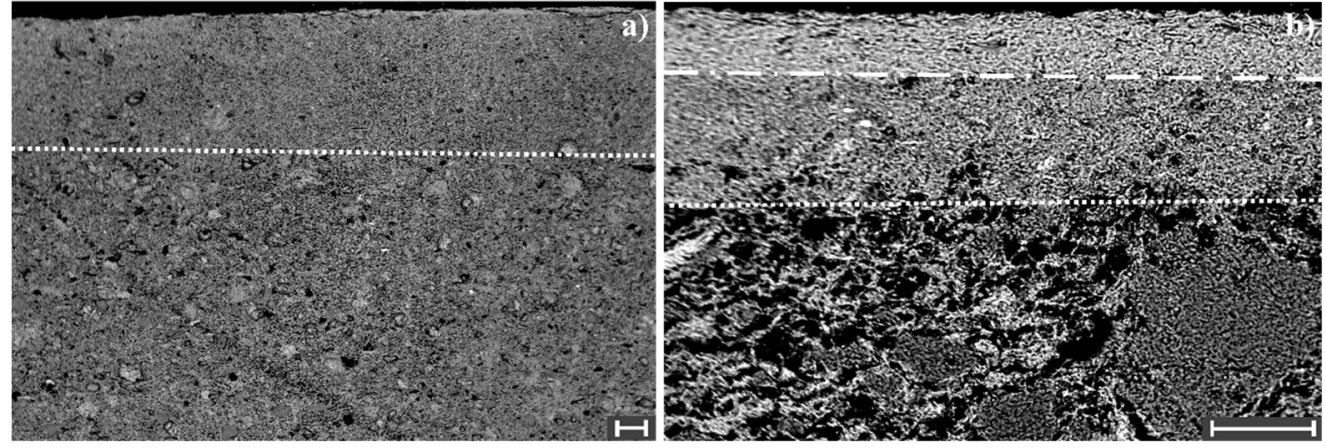

Figure 10. SEM-BSE photomicrographs of thin sections of fragments from Taranto (a) and Monte Sannace (b). The dashed lines separate red engobe layer (upper) from ceramic body (lower), showing the more compact and finer paste of engobe layer with respect to the ceramic body. Scale 100 micron.

Experimental data have suggested that the coarse fraction of clay -generally discarded by Attic potters- was used for the ceramic body, with the elutriated fraction being used for the red engobe. This hypothesis can be deduced from the comparison between the morphological and minero-petrographical characteristics of the ceramic body and the engobe. The engobe layer with respect to the ceramic body is more compact and finer, richer in matrix and poorer in silt. The same minerals are present, but their quantitative ratio is different: more quartz and feldspars in the body, more micas (biotites and muscovites) and clayey minerals in the engobe.

Chemical analysis allows to discriminate samples from the same site, according to the employed production technology [8]. Figure 11 shows the results obtained from the NLPCA analysis for the samples of three sites-Monte Sannace, Egnazia and Taranto-in which the presence of the two different production technologies has been highlighted. It is evident that the samples differ in provenance and, in case of the same origin, in production technology. The $R^{2}$ value of 0.86 and the Lof of 0.37 show that the best fitting model is built with 3 PCs.

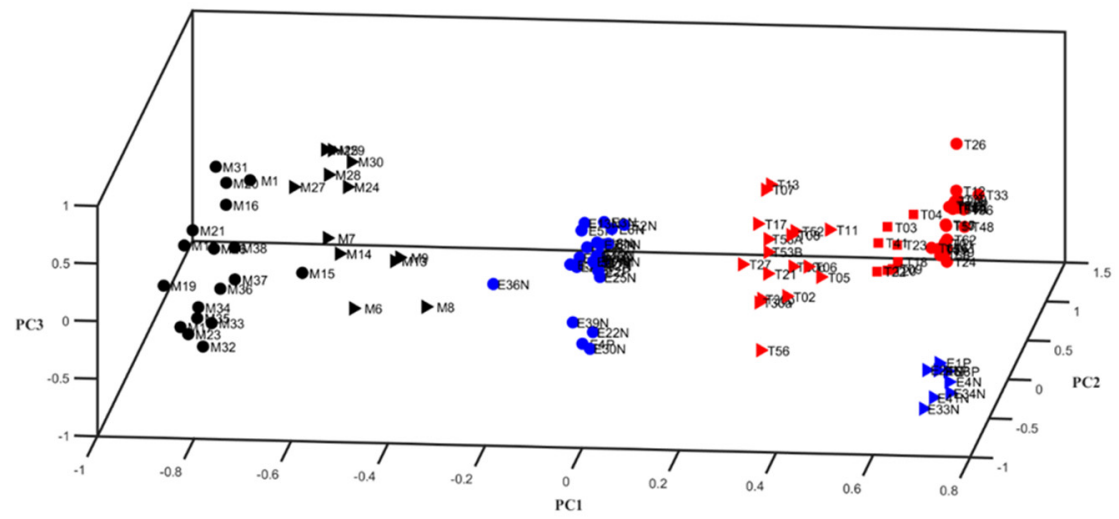

Figure 11. NLPCA scores plot of the samples belonging to Monte Sannace (black), Egnatia (blue) and Taranto (red). Circles and squares: classical Attic technology, triangles: Apulian technology.

The causes leading to the development of this new technology during the fourth century BCE are yet unclear. Was it the need for a more suitable raw material for the 
manufacture of the monumental vases which were typical of late production or was it to reduce manufacturing costs of items aimed at less well-off customers? This second hypothesis seems more likely since red engobe has not up to now been found on vases attributed to famous painters and/or coming from tombs referable to the aristocratic classes [28,30,31].

It is noteworthy to underline the presence of engobe on the firing tester [100] from Tarantine workshop mentioned in paragraph 2.2 and, based on the results obtained from the analysis of the paste, manufactured in the town.

\section{Concluding Remarks}

While stressing that the best methodological approach to the study of archaeological finds not only has to merge morphological-stylistic studies to scientific ones, but also to embrace a coordinate instrumental strategy, the results here outlined strongly highlight the relevance of metallic elements investigation in case of archaeological ceramic study. Their presence and/or quantification have shown their relevance, replying a high number of archaeological queries.

It has been highlighted, for example, how the presence of certain elements in the ceramic body, in larger quantities than trace ones, can provide important clues to the non-originality of pieces, probably integrated during an undocumented "restoration" and that the specific element can also supply information about the period this integration occurred. In the ceramic class here investigated, e.g., the presence of $\mathrm{Pb}$ in quantities higher than 200 ppm in the clay material used to produce the nonoriginal parts of the vessels has proved to be an indication of a contamination due to the materials used to obtain the black coating. The use of $\mathrm{Pb}$, instead of $\mathrm{Fe}$, to realize the black coating simulating the original black gloss is characteristic of nineteenth century restorations, which took place before the ferrous nature of the original black coating (black gloss) was determined.

It has been also pointed out how the potential information resources in the matrix of compositional data are not limited to the provenance of finds but it can also provide indications on manufacturing period [8] and production technology.

From an analytical point of view, it has been confirmed that the use of the NLPCA -nonlinear generalization of standard PCA by replacing linear surfaces with curved ones and considering hierarchical NLPCA based on the autoassociative neural network model method is more appropriate than PCA to treat archaeometric data, allowing to extract a greater amount of information from them.

It has been shown how it is possible by a single analysis to discriminate samples from the different production areas and manufactured with two different technologies. Excellent results have been obtained also with the application of LDA and QDA for the creation of classification models. The NER values obtained are always bigger than the $96 \%$, so the samples are correctly classified in the class previously assigned. The models built could be used in future applications as a training set using for projecting unknown samples, as a test set, and for predicting the belonging class.

Author Contributions: L.C.G. performed the bibliographic research and wrote the manuscript along with A.M.; L.C.G., T.F. and A.M. performed statistical treatments and A.M. provided helpful discussions and revised the manuscript. All authors have read and agreed to the published version of the manuscript.

Funding: This research received no external funding.

Conflicts of Interest: The authors declare no conflict of interest.

\section{References}

1. Hein, A.; Kilikoglou, V. Ceramic raw materials: How to recognize them and locate the supply basins: Chemistry. Archaeol. Anthropol. Sci. 2020, 12, 180. [CrossRef]

2. Mommsen, H.; Sjöberg, B.L. The importance of the 'best relative fit factor' when evaluating elemental concentration data of pottery demonstrated with Mycenaean sherds from Sinda, Cyprus. Archaeometry 2007, 49, 357-369. [CrossRef] 
3. Glascock, M.D.; Neff, H.; Vaughn, K.J. Instrumental Neutron Activation Analysis and Multivariate Statistics for Pottery Provenance. Hyperfine Interact. 2004, 154, 95-105. [CrossRef]

4. i Garrigós, J.B. Alteration and contamination of archaeological ceramics: The perturbation problem. J. Archeol. Sci. 1999, 26, 295-313. [CrossRef]

5. Eramo, G.; Giannossa, L.C.; Rocco, A.; Mangone, A.; Graziano, S.F.; Laviano, R. Oil lamps from the catacombs of canosa (Apulia fourth to sixth centuries ad): Technological features and typological imitation. Archaeometry 2014, 56, 375-391. [CrossRef]

6. Giannossa, L.C.; Acquaviva, M.; Laganara, C.; Laviano, R.; Mangone, A. Applications of a synergic analytical strategy to figure out technologies in medieval glazed pottery with negative decoration from Italy. Appl. Phys. A 2014, 116, 1541-1552. [CrossRef]

7. Giannossa, L.C.; Acquaviva, M.; De Benedetto, G.E.; Acquafredda, P.; Laviano, R.; Mangone, A. Methodology of a combined approach: Analytical techniques to identify the technology and raw materials used in thin-walled pottery from Herculaneum and Pompeii. Anal. Methods 2014, 6, 3490-3499. [CrossRef]

8. Mangone, A.; Giannossa, L.C.; Ciancio, A.; Laviano, R.; Traini, A. Technological features of Apulian red figured pottery. J. Archaeol. Sci. 2008, 35, 1533-1541. [CrossRef]

9. Mangone, A.; Giannossa, L.C.; Laganara, C.; Laviano, R.; Traini, A. Manufacturing expedients in medieval ceramics in Apulia. J. Cult. Herit. 2009, 10, 134-143. [CrossRef]

10. Mangone, A.; De Benedetto, G.E.; Fico, D.; Giannossa, L.C.; Laviano, R.; Sabbatini, L.; Traini, A. Multianalytical study of archaeological faience from Vesuvian area as a valid tool to investigate provenance and technological features. New J. Chem. 2011, 35, 2860-2968. [CrossRef]

11. Mangone, A.; Caggiani, M.C.; Giannossa, L.C.; Eramo, G.; Redavid, V.; Laviano, R. Diversified production of red figured pottery in Apulia (Southern Italy) in the late period. J. Cult. Herit. 2013, 14, 82-88. [CrossRef]

12. Aruga, R.; Mirti, P.; Casoli, A. Application of multivariate chemometric techniques to the study of Roman pottery (terra sigillata). Anal. Chi. Acta 1993, 276, 197-204. [CrossRef]

13. Mangone, A.; Giannossa, L.C.; Laviano, R.; Fioriello, C.S.; Traini, A. Investigations by various analytical techniques to the correct classification of archaeological finds and delineation of technological features. Late Roman lamps from Egnatia: From imports to local production. Microchem. J. 2009, 91, 214-221. [CrossRef]

14. Mirti, P.; Gulmini, M.; Pace, M.; Elia, D. The provenance of red figure vases from Locri Epizephiri (southern Italy): New evidence by chemical analyses. Archaeometry 2004, 46, 183-200. [CrossRef]

15. Mirti, P.; Perardi, A.; Gulmini, M.; Preacco, M.C. A scientific investigation in the provenance and technology of a black-figure amphora attributed to the Priam group. Archaeometry 2006, 48, 31-43. [CrossRef]

16. Massart, D.L.; Vandeginste, B.G.; Deming, S.N.; Michotte, Y.; Kaufman, L. Principal Components and Factor Analysis Chemometrics: A Textbook; Elsevier: Amsterdam, The Netherlands, 1988.

17. Neff, H. Chemical Characterization of Ceramic Pastes in Archaeology; Prehistory Press: Madison, WI, USA, 1992.

18. Aruga, R. The problem of responses less than the reporting limit in unsupervised pattern recognition. Talanta 2004, 62, 871-878. [CrossRef]

19. Bellanti, F.; Tomassetti, M.; Visco, G.; Campanella, L. A chemometric approach to the historical and geographical characterization of different terracotta finds. Microchem. J. 2008, 88, 113-120. [CrossRef]

20. Pizarro, C.; Pérez del Notario, N.; Sáenz González, C.; Rodríguez Tecedor, S.; González Sáiz Depa, J.M. Matching past and present ceramic production in the banda area (Ghana). Archaeometry 2012, 54, 101-113. [CrossRef]

21. Remolà, J.A.; Lozano, J.; Ruisánchez, I.; Larrechi, M.S.; Rius, F.X.; Zupan, J. New chemometric tools to study the origin of amphorae produced in the Roman Empire. Trends Anal. Chem. 1996, 15, 137-150. [CrossRef]

22. Maggetti, M. Phase analysis and its significance for technology and origin. In Archeological Ceramics; Olin, J.S., Ed.; Smithsonian Institution Press: Boston, MA, USA, 1982; pp. 121-133.

23. Maggetti, M.; Neururer, C.; Ramseyer, D. Temperature evolution inside a pot during experimental surface (bonfire) firing. Appl. Clay Sci. 2011, 53, 500-508. [CrossRef]

24. Maritan, L.; Nodari, L.; Mazzoli, C.; Milano, A.; Russo, U. Influence of firing conditions on ceramic products: Experimental study on clay rich in organic matter. Appl. Clay Sci. 2006, 31, 1-15. [CrossRef]

25. Riccardi, M.P.; Messiga, B.; Duminuco, P. An approach to the dynamics of clay firing. Appl. Clay Sci. 1999, 15, 393-409. [CrossRef]

26. Tite, M.S. Firing temperature determinations how and why? In The Aim of Laboratory Analyses of Ceramics in Archeology, Proceedings of the Kungliga Vitterhets Historie Och Antikvitets Akademien Konferenser, Lund, Sweden, 7-9 April 1995; Coronet Books Inc: Philadelphia, PA, USA, 1995; Volume 34, pp. 37-42, ISBN 91-7402-258-X.

27. Giannossa, L.C.; Laviano, R.; Mastrorocco, F.; Giannelli, G.; Muntoni, I.M.; Mangone, A. A pottery jigsaw puzzle: Distinguish true and false pieces in two Apulian red figured vases by a poli-technique action plan. Appl. Phys. A 2016, 122, 68-77. [CrossRef]

28. Giannossa, L.C.; Giacobello, F.; Muntoni, I.M.; Laviano, R.; Caggiani, M.C.; Mastrorocco, F.; Mangone, A. An analytical techniques pool to hit the target. A comprehensive examination on an Apulian red figured pottery collection. Microchem. J. 2017, 134, 354-361. [CrossRef]

29. Giannossa, L.C.; Mininni, R.M.; Laviano, R.; Mastrorocco, F.; Caggiani, M.C.; Mangone, A. An archaeometric approach to gain knowledge on technology and provenance of Apulian red figured pottery from Taranto. Archaeol. Anthrop. Sci. 2017, 9, 1125-1135. [CrossRef] 
30. Giannossa, L.C.; Muntoni, I.M.; Laviano, R.; Mangone, A. Contribution of mineralogical and analytical techniques to investigate provenance and technologies of Hellenistic pottery from Arpi (Southern Italy). J. Archaeol. Scie. Rep. 2019, 24, 729-737. [CrossRef]

31. Giannossa, L.C.; Muntoni, I.M.; Laviano, R.; Mangone, A. Building a step by step result in archaeometry. Raw materials, provenance and production technology of Apulian Red Figure pottery. J. Cult. Herit. 2020, 43, 242-248. [CrossRef]

32. Mangone, A.; Giannossa, L.C.; Colafemmina, G.; Laviano, R.; Traini, A. Use of various spectroscopy techniques to investigate raw materials and define processes in the overpainting of Apulian red figured pottery (4th century BC) from Southern Italy. Microchem. J. 2009, 92, 97-102. [CrossRef]

33. Trendall, A.D.; Cambitoglou, A. The Red-Figured Vases of Apulia, Volume I: Early and Middle Apulian. Am. J. Archeol. 1980, 84, 110-112.

34. Trendall, A.D.; Cambitoglou, A. The Red-Figured Vases of Apulia, Volume II: Late Apulian. L'Antiquité Classique 1985, 54, 529-531.

35. Trendall, A.D. Red Figure Vases of South Italy and Sicily (World of Art) A Handbook; Thames \& Hudson: London, UK, 1989.

36. Mangone, A.; Giannossa, L.C.; Ciancio, A.; Laviano, R.; Traini, A. Indagini Archeometriche Sulla Ceramica Apula a Figure Rosse Proveniente da Siti della Puglia Centrale, Proceedings of the Atti convegno di archeometria della Ceramica, Rutigliano, Bari, Italy, 18 January 2004; Ciancio, A., Ed.; L'artigiangrafica Guarnieri: Rutigliano, Italy, 2008; pp. 83-103.

37. Aloupi-Siotis, E. Recovery and revival of attic vase-decoration techniques. What can it offer to archaeological research? In Papers on Special Techniques in Athenian Vases, Proceedings of The Colors of Clay: Special Techniques in Athenian Vases; Lapatin, K., Ed.; Getty Pubblications: Los Angeles, CA, USA, 2008; pp. 113-127.

38. Aloupi-Siotis, E. Ceramic technology: How to haracterize black Fe-based glass-ceramic coatings. Archaeol. Anthropol. Sci. 2020, 12, 191. [CrossRef]

39. Bente, K.; Sobott, R.; Berthold, C. Phase analytical and microstructural study of black glosses on Attic red-figure vases by XRD (GADDS), Mössbauer spectroscopy, and TEM. In Naturwissenschaftliche Analysen vor und fruhgeschichtlicher Keramik 3. Methoden, Anwendungsbereiche, Auwertungmoglichkeiten; Ramminger, B., Stillborg, O., Helfert, M., Eds.; Universitätsforschungen zur prähistorischen Archäologie: Bonn, Germany, 2013; pp. 273-288.

40. Bimson, M. The technique of Greek Black and Terra Sigillata red. Antiq. J. 1956, 36, 200-204. [CrossRef]

41. Binns, C.F.; Fraser, A.D. Genesis of the Greek Black Glaze. Am. J. Archaeol. 1929, 33, 1-9. [CrossRef]

42. Chaviara, A.; Aloupi-Siotis, E. The story of a soil that became a glaze: Chemical and microscopic fingerprints on the Attic vases. $J$. Archaeol. Scie. Rep. 2016, 7, 510-518. [CrossRef]

43. Cianchetta, I.; Trentelman, K.; Maish, J.; Saunders, D.; Foran, B.; Walton, M.; Pianetta, P. Evidence for an unorthodox firing sequence employed by the Berlin Painter: Deciphering ancient ceramic firing conditions through high resolution material characterization and replication. J. Anal. At. Spectrom. 2015, 30, 666-676. [CrossRef]

44. Cianchetta, I.; Maish, J.; Saunders, D.; Walton, M.; Mehta, A.; Foran, B.; Trentelman, K. Investigating the firing protocol of Athenian pottery production: A Raman study of replicate and ancient sherds. J. Raman Spectrosc. 2015, 46, 996-1002. [CrossRef]

45. Cianchetta, I.; Trentelman, K.; Walton, M.S.; Maish, J.; Mehta, A.; Foran, B.; Cianchetta, I.; Trentelman, K.; Walton, M.S.; Maish, J.; et al. Reverse Engineering Ancient Greek Ceramics: Morphological and Spectral Characterization of Replicates. J. Am. Ceram. Soc. 2016, 99, 1792-1801. [CrossRef]

46. Farnsworth, M.; Wisely, H. Fifth century intentional red glaze. Am. J. Archaeology 1958, 62, 165-173. [CrossRef]

47. Farnsworth, M.; Simmons, I. Colouring agents for Greek glazes. Am. J. Archaeol. 1963, 67, 389-396. [CrossRef]

48. Hofmann, U. The chemical basis of ancient Greek vase painting. Angew. Chem. 1962, 1, 341-350. [CrossRef]

49. Hofmann, U. Die Chemie der antiken Keramik. Naturwissenshaften 1966, 53, 218-223. [CrossRef]

50. Ingo, G.M.; Bultrini, G.; de Caro, T.; Del Vais, C. Microchemical study of the black gloss on red and black-figured Attic vases. Surf. Interface Anal. 2000, 30, 101-105. [CrossRef]

51. Jones, R.E. Greek and Cypriot Pottery: A Review of Scientific Studies; British School at Athens: Athens, Greece, 1986.

52. Kingery, W.D. Attic pottery gloss technology. Archeomaterials 1991, 5, 47-54.

53. Longworth, G.; Tite, M.S. Mossbauer studies on the nature of red or black glazes on Greek and Indian painted ware. J. Phys. 1979, 40, 460-461. [CrossRef]

54. Lühl, L.; Hesse, B.; Mantouvalou, I.; Wilke, M.; Mahlkow, S.; Aloupi-Siotis, E.; Kanngiesser, B. Confocal XANES and the Attic Black Glaze: The Three-Stage Firing Process through Modern Reproduction. Anal. Chem. 2014, 86, 6924-6930. [CrossRef]

55. Maniatis, Y.; Aloupi, E.; Stalios, A.D. New evidence for the nature of the Attic black gloss. Archaeometry 1993, 35, 23-34. [CrossRef]

56. Mirti, P. X-ray microanalysis discloses the secrets of ancient Greek and Roman potters. X-ray Spectrom. 2000, 29, 63-72. [CrossRef]

57. Naudé, C.P. The glaze technique of the Attic vase. In Acta Classica 2, Proceedings of the Classical Association of South Africa; Classical Association of South Africa: Pretoria, South Africa, 1959; pp. 106-116.

58. Noble, J.V. The technique of Attic vase painting. Am. J. Archaeology 1960, 64, 307-313. [CrossRef]

59. Noble, J.V. The Techniques of Painted Attic Pottery; Watson-Guptill Publications: New York, NY, USA, 1965.

60. Noll, W.; Holm, R.; Born, L. Material und techniken antiker vasenmalerei. Jahrbuch der Staatlichen Kunstsammlungen; Band X: Baden-Wurttemberg, Germany, 1973; Volume 1, pp. 103-126.

61. Noll, W.; Holm, R.; Born, L. Bemalung antiker Keramik. Angew. Chem. 1975, 87, 639-651. [CrossRef]

62. Noll, W.; Holm, R.; Born, L. Painting of Ancient Ceramics. Angew. Chem. Int. Ed. 1975, 4, 602-613. (In English) [CrossRef]

63. Pavicevic, M. Untersuchung der schwarzen Malschicht attischer Vasen mit der Elektronenmikrosonde. Ber. Dt. Keram. Ges. 1974, 51, 61-63. 
64. Robinson, E. Archaeometric analysis of Apulian and Lucanian red-figure pottery. In The Italic People of Ancient Apulia: New Evidence from Pottery for Workshops, Markets and Customs; Carpenter, T., Lynch, K., Robinson, E., Eds.; Cambridge University Press: Cambridge, UK, 2014; pp. 243-264.

65. Schumann, T. Oberflachenverzierung in der antiken Topferkunst, Terra sigillata und griechische Schwarzrotmalerei. Ber. Dt. Keram. Ges. 1942, 23, 408-426.

66. Tang, C.C.; MacLean, E.J.; Roberts, M.A.; Clarke, D.T.; Pantos, E.; Prag, A.J. The study of Attic black gloss sherds using synchrotron X-ray diffraction. J. Archaeol. Sci. 2001, 28, 1015-1024. [CrossRef]

67. Tite, M.S.; Bimson, M.; Freestone, I.C. An examination of the high gloss surfaces finishes on Greek Attic and Roman Samian wares. Archaeometry 1982, 24, 117-126. [CrossRef]

68. Walton, M.; Trentelman, K.; Cummings, M.; Poretti, G.; Maish, J.; Saunders, D. Material Evidence for Multiple Firings of Ancient Athenian Red-Figure Pottery. J. Am. Ceram. Soc. 2013, 96, 2031-2035. [CrossRef]

69. Walton, M.; Trentelman, K.; Cianchetta, I.; Maish, J.; Saunders, D.; Foran, B.; Mehta, A. Zn in Athenian black gloss ceramic slips: A trace element marker for fabrication technology. J. Am. Ceram. Soc. 2014, 98, 430-436. [CrossRef]

70. Winter, A. Die Technik des giechischen Topfers in ihren Grundlagen, Tech Beitrage zur Archaologie 1; Rom germanisches Zentralmuseum: Mainz, Germany, 1959.

71. Artal-Isbrand, P.; Klausmeyer, P. Evaluation of the relief line and the contour line on Greek red-figure vases using reflectance transformation imaging and three-dimensional laser scanning confocal microscopy. Stud. Conserv. 2013, 58, 338-359. [CrossRef]

72. Pérez, J.M.; Esteve-Tébar, R. Pigment identification in Greek pottery by Raman microspectroscopy. Archaeometry 2004, 46, 607-614. [CrossRef]

73. Ambrosini, L.; Felici, A.C.; Fronterotta, G.; Piacentini, M.; Vendittelli, M. Non Destructive Analysis of a Red Figure Vase of Uncertain Attribution from Falerii Veteres. In Proceedings of the EMAC'07 9th European Meeting on Ancient Ceramics, Budapest, Hungary, 24-27 October 2007; Birò, K., Szilàgyi, V., Kreiter, A., Eds.; Hungarian National Museum: Budapest, Hungary, 2007.

74. Barilaro, D.; Crupi, V.; Interdonato, S.; Longo, S.; Maisano, G.; Majolino, D.; Venuti, V.; Barone, G.; Mazzoleni, P.; Tigano, G.; et al. Archaeometric investigation of red-figure pottery fragments from Gioiosa Guardia (Messina, Sicily) by INAA, FT-IR and TOF-ND techniques. Il Nuovo Cimento C 2008, 31, 371-388, ISSN 1826-9885.

75. Bitetto, A.; Mangone, A.; Mininni, R.M.; Giannossa, L.C. A nonlinear principal component analysis to study archeometric data. J. Chemometrics 2016, 30, 405-415. [CrossRef]

76. Grave, P.; Robinson, E.; Barbetti, M.; Yu, Z.; Bailey, G.; Bird, R. Analysis of south Italian pottery by PIXE-PIGME. Meditarch 1997, 9/10, 113-125.

77. Mastrorocco, F. Chemical and Molecular Sciences, Innovative Approach in LA-ICPMS Implementation Cases in Cultural Heritage by NPs Deposition. Ph.D. Thesis, University of Bari Aldo Moro, Bari, Italy, 2015-2018.

78. Mirti, P.; Casoli, A.; Barra Bagnasco, M.; Preacco Ancona, M.C. Fine ware from Locri Epizephiri: A provenance study by Inductively Coupled Plasma Emission Spectroscopy. Archaeometry 1995, 37, 41-51. [CrossRef]

79. Thorn, J.; Glascock, M. New evidence for Apulian red-figure production centres. Archaeometry 2010, 52, 777-795. [CrossRef]

80. Laviano, R.; Muntoni, I.M. Analisi archeometriche sulle ceramiche a figure rosse dalla tomba 33 di Timmari: Provenienza delle materie prime e tecnologie di manifattura di alcune opere del Pittore di Dario. In Una Tomba Principesca da Timmari; Canosa, M., Bretschneider, G., Eds.; Accademia Nazionale dei Lincei: Roma, Italy, 2007; pp. 179-205.

81. Mangone, A.; Giannossa, L.C.; Caggiani, M.C.; Laviano, R.; Redavid, V.; Traini, A. Late Red Figured Pottery from Egnatia (Southern Italy): Attic Tradition and Apulian technological Innovation, Proceedings of the 4th International Congress on Science and Technology for the Safeguard of Cultural Heritage in the Mediterranean Basin, Cairo, Egypt, 6-8 December 2009; Grafica Eletronica srl: Naples, Italy, 2010; pp. 321-326, ISBN 978-88-96680-32-2.

82. Mangone, A.; Giannossa, L.C.; Colafemmina, G.; Laviano, R.; Redavid, V.; Traini, A. Gnathia and Red Figured Pottery from Apulia: Continuity of a Production Technology. In Proceedings of the International Symposium on Archaeometry, Siena, Italy, 12-16 May 2008; Springer: Berlin, Germany, 2011; pp. 99-104.

83. Mirti, P.; Casoli, A.; Calzetti, L. Technology of production of fine pottery excavated on a western Greek site investigated by Scanning Electron Microscopy coupled with Energy-Dispersive X-ray detection. X-ray Spectrom. 1996, 25, 103-109. [CrossRef]

84. Mirti, P.; Gulmini, M.; Perardi, A.; Davit, P.; Elia, D. Technology of production of red figure pottery from Attic and southern Italian workshops. Anal. Bional. Chem. 2004, 380, 712-718. [CrossRef]

85. Barca, D.; La Russa, M.F.; Crisci, G.M. Technological and geochemical study of two red-figured vases of unknown provenance by various analytical techniques. Appl. Phys. A 2010, 100, 911-917. [CrossRef]

86. Bonacci, P.; Guiducci, S. Alla Ricerca Dell'Arte Perduta; Il Formichiere: Perugia, Italy, 2018.

87. Hatcher, H.; Hedges, R.E.M.; Pollard, A.M.; Kenrick, P.M. Analysis of Hellenistic and Roman fine pottery from Benghazi. Archaeometry 1980, 22, 133-151. [CrossRef]

88. Miller, J.N.; Miller, J.C. Statistics and Chemometrics for Analytical Chemistry, 6th ed.; Prentice Hall: Upper Saddle River, NJ, USA, 2009.

89. Alaimo, R.; Bultrini, G.; Eragalà, I.; Giarrusso, R.; Illiopoulos, I.; Montana, G. Archaeometry of Sicilian glazed pottery. Appl. Phys. A Mater. Sci. Process. 2004, 9, 221-227. [CrossRef] 
90. Vannoorenberghe, M.; Van Acker, T.; Belza, J.; Teetaert, D.; Crombé, P.; Vanhaecke, F. Multi-element LA-ICP-MS analysis of the clay fraction of archaeological pottery in provenance studies: A methodological investigation. J. Anal. At. Spectrom. 2020, 35, 2686-2696. [CrossRef]

91. Hall, M.E. Pottery styles during the early Jomon period: Geochemical perspectives on the Moroiso and Ukishima pottery styles. Archaeometry 2007, 43, 59-75. [CrossRef]

92. Ripley, B.; Venables, B.; Bates, D.M.; Hornik, K.; Gebhardt, A.; Firth, D. Package 'MASS'. Cran-R Project; The R Foundation: Vienna, Austria, 2019.

93. Stacklies, W.; Redestig, H.; Scholz, M.; Walther, D.; Selbig, J. The 'pcaMethods' Package. Bioinformatics; Max Planck Institute for Molecular Plant Physiology: Potsdam, Germany, 2007.

94. Knelman, J. A brief history of art theft. Queens Quart. 2011, 118, 222-233.

95. Chen, F.; Regan, R. Arts and craftiness: An economic analysis of art heists. J. Cult. Econ. 2017, 41, 283-307. [CrossRef]

96. Amineddoleh, L. The Role of Museums in the Trade of Black Market. Cultural Heritage Property. Art Antiq. Law 2013, 18, 227-254.

97. Melillo, L.; Operetto, M. Pittore di Varrese (attribuito a) Loutrophoros apula a figure rosse 350-340 a.C., relazione di restauro. In Restituzioni 2013; Bertelli, C., Bonsanti, G., Eds.; Tesori D’Arte Restaurati, Marsilio: Venice, Italy, 2013.

98. Giannossa, L.C. Ceramica Apula a Figure Rosse: Indagine Archeometrica di Reperti dai Siti di Monte Sannace ed Arpi. Master's Thesis, Dipartimento di Chimica, Università degli Studi di Bari Aldo Moro, Bari, Italy, 2004-2005.

99. Mangone, A.; Laviano, R.; Giannossa, L.C.; Muntoni, I.M. Archeometria di due Restauri. Giornata Internazionale di Studio-SavoirFaire Antichi e Moderni: Tra Ruvo di Puglia e Napoli. Il Caso del Cratere dell'Amazzonomachia e di Una Loutrophoros con il mito di Niobe; Giacobello, F., Pouzadoux, C., Eds.; Centre Jean Berard: Naples, Italy, 2020; pp. 95-110.

100. Castoldi, M. I vasi a figure rosse del periodo protoapulo e apulo antico: Taranto e le officine ceramiche. In Ceramiche Attiche e Magnogreche, Collezione Banca Intesa; Sena Chiesa, G., Slavazzi, F., Eds.; Electa: Milano, Italy, 2006; pp. $178-181$.

101. Dell'Aglio, A. La forma della città: Aree e strutture di produzione artigianale. Taranto e il Mediterraneo. In Proceedings of the 41st Convegno di Studi sulla Magna Grecia, Taranto, Italy, 2-16 October 2001; Istituto per la storia e l'archeologia della Magna Grecia: Taranto, Italy, 2002; pp. 171-193.

102. De Juliis, E.M. La Tomba del Vaso dei Niobidi di Arpi; Edipuglia: Bari, Italy, 1992.

103. Corrente, M. 1912 un Ipogeo al Confine: La Tomba Varrese; Alfagrafica Volonnino: Potenza, Italy, 2004.

104. Giacobello, F. Pittore di Dario (attribuito a) Kratere apulo a figure rosse detto 'Vaso dell'Amazzonomachia' 330 a.C. ca. In Restituzioni 2013; Bertelli, C., Bonsanti, G., Eds.; Tesori d'arte restaurati: Venezia, Italy, 2013; pp. 78-83. 